\title{
RURAL SOCIETY IN AFGHANISTAN
}

\author{
Nancy Hatch Dupree \\ Director, Afghanistan Centre at Kabul University \\ Kabul, Afghanistan
}

The research paper surveys the population of rural Afghanistan in the context of its proximity to the archaeological sites. The population and its relationship discussion focuses on Afghanistan's regional position, highlighting certain aspects of the environment that affect rural life, followed by some efforts to reach out to rural populations. Mentioned throughout are significant attitudinal changes that have taken place since the nation stepped from the shadows of isolation onto the global stage just a little over one century ago.

Keywords: Afghanistan, Baghlan, Family, Kushans, Oxus

Afghanistan - a land of majestic mountain beauty where small towns cluster on fertile plains here and straddle rivers there, where villages mantled by orchards cling to barren mountain slopes above grasslands that give way to an array of semi, sandy, stony and salty deserts crisscrossed by diverse types of irrigation systems that ultimately succumb to vast desert wastes. These extremes of nature cover an area of some 652,230 square kilometers inhabited by a vaguely estimated population of between twenty-four and thirty-five million. This broad range stems from the fact that no complete official census figures are available. Various sources use an assortment of estimates to promote their interests.

The total population in 1979 was said to be twenty-four million with eighty-five per cent inhabiting rural areas. A much quoted estimated total population of 31.3 million for 2014 with some seventy-seven percent living in rural areas, includes an estimated six percent of the nomadic population which has settled down owing to conversion of pasture lands for agricultural development, an improved transportation infrastructure, war-disrupted migration routes and a substantial loss of livestock during years of drought and conflict. The projected growth rate is 2.25 percent for rural areas, in contrast to a 4.7 percent rate for urban centers suggesting a high rate of migration away from rural areas. In addition, there are also some three million or more Afghan refugees living abroad, many of whom are from rural areas. A caveat: Afghan statistics vary enormously and should be viewed with caution. 
Also, it must be kept in mind that an escalating Afghan Taliban insurgency movement disturbs many of the patterns discussed below. The ultra-conservative Taliban imposed their strict interpretations of Islam Law during their reign, beginning in 1996 until they were ousted by international forces in October 2001 ${ }^{1}$. Having regrouped, they now lead vigorous campaigns against the Kabul government and decadent western intrusions, almost daily attacking government intuitionsall across the country. Army and police posts are particularly vulnerable.

This discussion focuses on Afghanistan's regional position, highlighting certain aspects of the environment that affect rural life, followed by some efforts to reach out to rural populations. Mentioned throughout are significant attitudinal changes that have taken place since the nation stepped from the shadows of isolation onto the global stage just a little over one century ago.

\section{THE GEOPOLITICAL HUB}

Archaeological evidence traces the progress taken by those living in the area now known as Afghanistan in moving from being hunters and gatherers to custodians of a hub linking four great cultures: Central Asian to the north, Chinese to the east, Persian to the west and Indian to the south. Small collections of early man-made tools dating from the Lower and Middle Paleolithic 50,000-100,000 years ago were recovered west of Ghazni ${ }^{2}$, as well as in Badakhshan and Faryab provinces. A more extensive assemblage of 20,000 thousand sophisticated finely made Upper Paleolithic flint implements, dating from 11-30,000 years ago, was excavated from caves at Aq Kupruk in Balkh province. Archaeological evidence also confirms north Afghanistan as one of the world's centers of plant and animal domestication some 9-11,000 years ago. This led to the rise of Neolithic farming villages. ${ }^{3}$

\footnotetext{
${ }^{1}$ Maley, 1998

${ }^{2}$ L. Dupree and Davis 1976, Pp. 13-37

${ }^{3}$ L. Dupree \&et al., , 1972
} 
Map. 1: Afghanistan Archaeological Sites

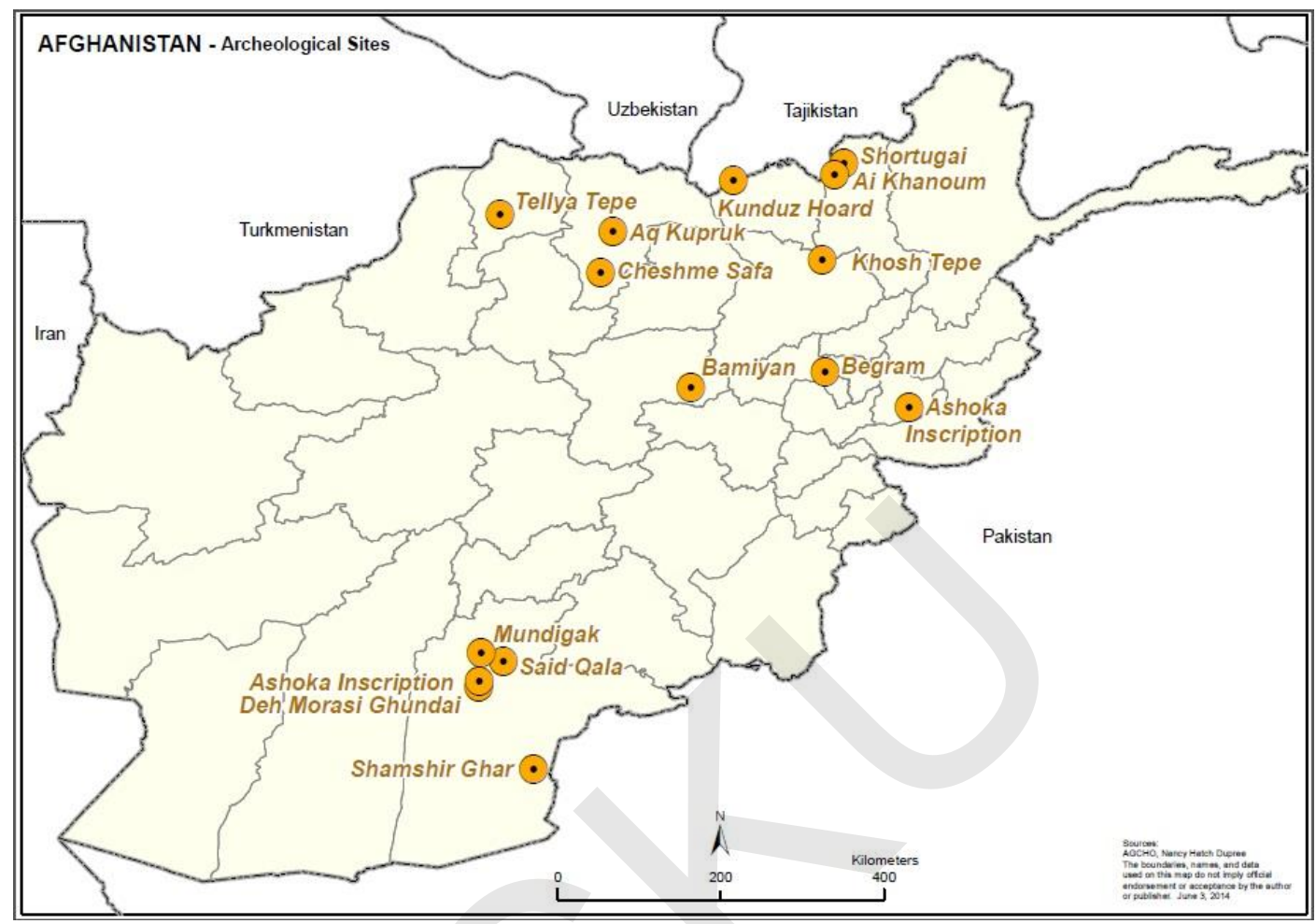

Source: Nancy Hatch Dupree, 2014

Families moved from their mountain caves onto the plains where planting was easier and water more available. Freed from time spent hunting and gathering, these early village populations soon accumulated food surpluses and developed specialties as potters and other artisans, administrators, and traders, paving the way for extensive trading during the following Bronze Age 3-1,000 years ago. Large concentrations of Neolithic tools as well as an infinite variety of Bronze Age trader's seals were collected from clusters of settlements south of the Amu Darya (Oxus) River in northern Faryab and Takhar provinces ${ }^{4}$.

The trading caravans carried a multitude of luxury items including lapis lazuli from Badakhshan which was prized as far a-field as Mesopotamia, Egypt and the Indus Valley. The seventeen gold and silver vessels dating from BCE 2,300 and 1,350 found at Khosh Tepe in Baghlan province, a scant fifty miles from the lapis lazuli mines, decorated with a mixture of Indian, Persian, Central Asian and Mesopotamian designs, substantiate the richness of this trade ${ }^{5}$. At Shortugai, a manufacturing and trading depot in Takhar province, a rhinoceros seal from the Indus Valley was found together with lapis lazuli fragments ${ }^{6}$.

${ }^{4}$ Ball, 1982

${ }^{5}$ L. Dupree, et al 1971a

${ }^{6}$ L. Dupree, 1981, 103-126 
In the south, in Kandahar province, an exceptional Bronze Age bone seal portraying a winged camel was found at the nomadic cave site of Shamshir Ghar. Bronze Age village sites at Deh Morasi Ghundai and Said Qala nearMundigak, itself originally a nomadic encampment that evolved into a densely populated town with large granaries supplying the great Indus Valley cities of Harappa and Mohenjo-daro, clearly served as the backbone of the local economy

Thus, there was much coming and going across this land from very early days. Trade brought wealth which attracted a distinguished roster of empire builders, including Darius I of Achaemenind Persia in the sixth century BCE when Afghanistan enters the historical records. Darius extended his empire as far as the Indus River, built highways to facilitate trade, and introduced the Aramaic language. Excavations atCheshme Shafa not far from Balkh city,the center of what was then called Bactria,reveal immense fortifications suggesting the need for strong military garrisons to protect the trade and control local revolts.

Alexander the Great of Macedon crushed the Achaeminids in the fourth century BCE and proceeded to dot the Afghan landscape with outposts at which the Greek language dominated. After his death in BCE 143, however, his successor lost the southern areas to India's Mauryan King Ashoka who confirmed local chieftains in their satrapies. The bilingual Aramaic and Greek Ashoka edicts found in Laghman province and in the city of Kandahar contain messages of compassion toward man and beast that are similar but not identical to the Ashoka Rock Edicts found in India.

In the Bactrian north, life was more turbulent. Here Hellenized Greek colonizers, including onetime dissidents exiled by the Achaeminids, ruled supreme after Diodotus declared independence in BCE 256. One can conceive of no greater images of regal power than the portraits adorning a cache of Greco-Bactrian coins found on the left bank of the Amu Darya north-west of Kunduz in Takhar province. On the reverses Greek inscriptions and Greek deities such as Zeus, Hercules and Athena strengthened ties to the west.

Even more revealing are the excavations at near-by Ai Khanoum. Beginning as a military outpost during the first half of the third century BCE, Ai Khanoum contained monumental edifices with prominent Greek features that included a many-columned administration center, villas with Greek and Oriental traits, temples of various sorts, one of the largest gymnasiums in the antique world, a grandiose theatre designed to seat five thousand, and an idyllic river-side plaza with fountain spouts in the form of a comedy masque, a dolphin and the head of a lion. Imposing statuary, elegant statuettes and inscriptions copied from Delphi were also found. Sadly, the grandeur of Ai Khanoum frequently attracted the attention of nomadic herders roaming the Central Asian steppes in search of pasturage north of the Amu Darya. In BCE 130 one final raid set this magnificent city ablaze burying it under ash and rubble.

That the steppe nomads who broke the hold of the Bactrians soon took to the ways of settled life is abundantly clear at the necropolis of Tellya Tepe outside Shibarghan in Jawjzan province (Sarianidi 1985). The 22,000 golden artifacts and ornaments found in seven tombs dating from the turn of the BCE-CE eras synthesize Oriental, Central Asian and Greco-Roman art styles in a manner that influenced the development of the later Gandharan art style that is extolled to this day. Among them a ring adorned with the goddess Athena enthroned attests to her continued 
popularity. A magnificent buckle carrying the image of a Roman soldier is another example of the variety of cultural influences brought through trade.

Politically, these nomadic peoples reached their greatest heights under the Kushan King Kanishka in the second century CE. He gained fame, wealth and power from the robust trade flowing along the famous Silk Route, from the eastern end if the Mediterranean across Central Asia to China, passing through the bustling depot at Balkh in Balkh province. A spectacular collection of trade items including Indian ivories, Greco-Roman bronzes and glassware from Egypt and lacquers from China recovered from a palace at Kanishka's summer capital just north of Kabul at Begram in Kapisa province points to the extent of this luxury trade as well as to the sybaritic lifestyles enjoyed by the Kushan aristocracy. ${ }^{7}$

Culturally, the contributions introduced by the Kushans were considerable. Tolerance in religion is indicated by the eclectic choice of thirty-three gods and goddesses chosen from the pantheons of Persia, Central Asia and India that appear on Kanishka's coinage, including Shiva and the first depiction of the Buddha in human form. Buddhist monasteries proliferated around Kabul, but the most extensive complex was at Bamiyan in Bamiyan province mid-way on the caravan route between Balkh and India. Here, surrounded by hundreds of man-made caves functioning as monastic centers, two colossal Buddha statues thirty-eight and fifty-five meters tall were carved into the sandstone cliffs around the sixth century.

Wall paintings throughout the valley point to the decline of the Kushans and the rise of the Persian Sassanians. But the paintings over the head of the Large Buddha depicting the pleasures of Paradise complete with scantily clad female dancers and musicians playing cymbals and harps are reminiscent of the art of India's Gupta dynasty at its zenith. Buddhism survived in these mountains long after its decline in its homeland in India. The laterseventh and eighth century paintingsfound at various sites throughout the area foretell the evolution of the mystical diagrams essential to Esoteric Buddhism practiced today in Tibet and Nepal.

New periods of turmoil now begin aswaves of Central Asian nomads again arrive in the fifth century followed by Arabs carrying the banner of Islam in the seventh. The Hindu Shahi Dynasty ruled the environs of Kabul in the seventh century while a plethora of squabbling fiefdoms, some Buddhist, some Hindu, jockeyed for power. Trade routes were disrupted and sea routes replaced the land routes

Over the next nine centuries the fury of fratricidal battles and devastating visitations by such as Genghis Khan and Tamerlane alternate with periods of high cultural attainment, most notably under the Ghaznavids at Ghazni in the eleventh century and at Timurid Herat in the fifteenth. By the sixteenth century the Afghan area swung on the periphery of the Moghul Empire in India and the Safarids in Persia, only momentarily unified in the eighteenth under the Kandahari Amir Ahmad Shah Durrani before it became enmeshed in the nineteenth century Great Games waged by Czarist Russian and British imperialists.

Neither the Russians nor British colonized Afghanistan. Instead they sought to create a buffer between their ambitions by drawing boundaries around it. Joint boundary commissions composed of Russians, Persians and Afghans began to mark the frontiers as early as 1869 but it

${ }^{7}$ Rowland, 1971 
took many years filled with acrimonious disputes that continue to this day for the boundaries cut through ethno-linguistic groups with common cultures. Abdur Rahman Khan, installed by the British as Amir of Kabul in 1880, set out immediately to bring the disparate people inside these borders firmly under his autocratic rule. Wary of outsiders, he permitted few foreigners to enter without his permission. For many years Afghanistan was dubbed a hermit nation.

\section{ECOLOGY AND RURAL SETTLEMENTS}

Towering mountain ranges with peaks as high as 2000 meters cover almost half of the Afghan land mass. This intimidating backbone of the nation is, however, one of the most fragile ecosystems in the world. The fountainheads of all four major river systems lie in these central mountains: the Kabul River moving east to join the mighty Indus in Pakistan; the HilmandArghandab rivers running south-west only to peter out in marshy lakes in Iran; the Hari Rud flowing west and then north to form part of the Afghanistan-Iranian border before entering Central Asia; and the great Amu Darya that serves as much of the northern border with Central Asia. Tributaries give life to chains of verdant valleys filled with fields and orchards.Access to water resources, however, is a major determinant in selecting locations for settlement. The problem is not an insufficiency of water, but its management.

Map. 2: Afghanistan-Provincial Population

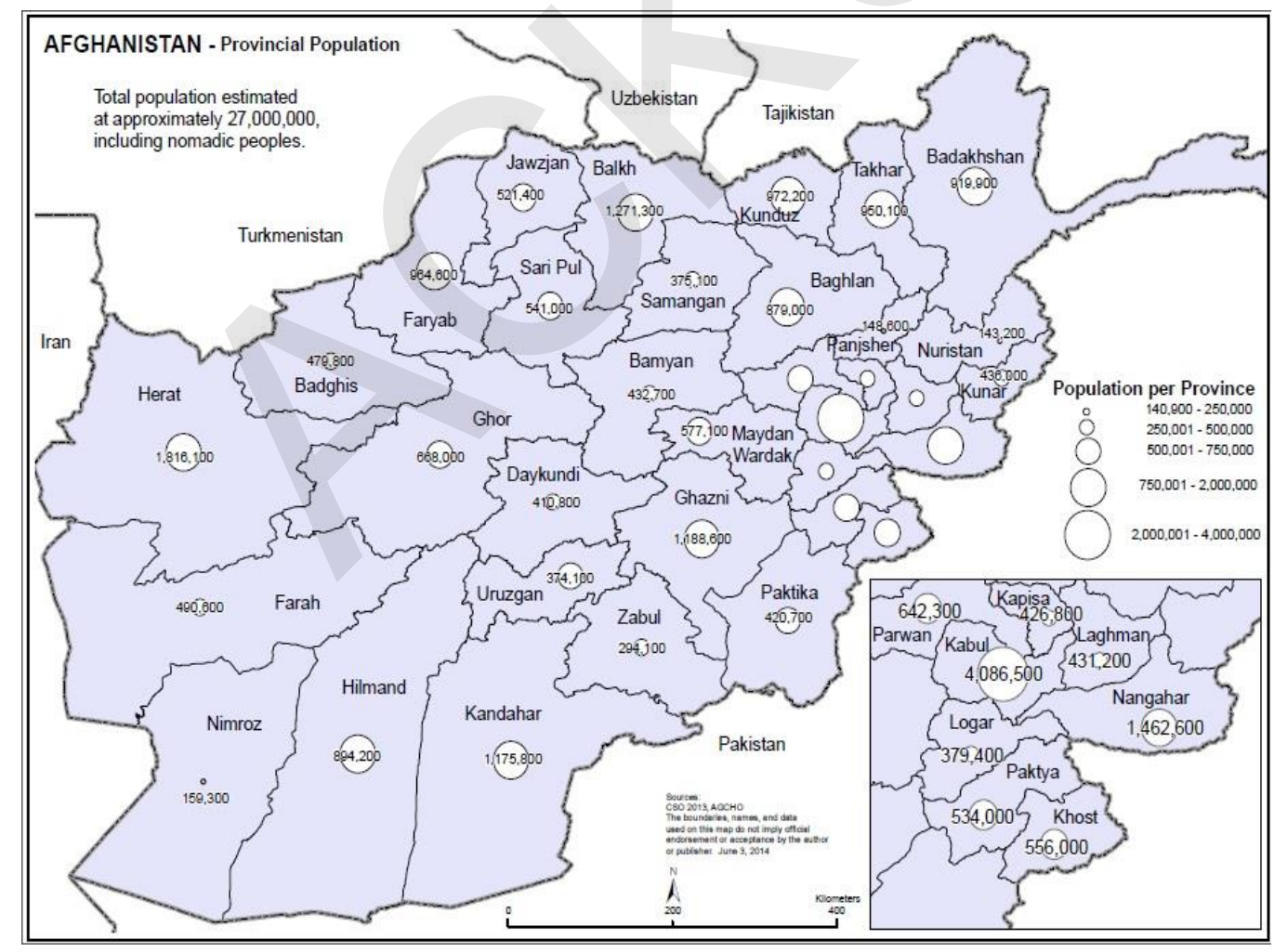

Source: Nancy Hatch Dupree, 2014

Recurring environmental disasters such as spring floods that continue from March until May and summer droughts can devastate rural populations. There are either too much or too little water 
because its distribution is inadequate and its management too often faulty, although the indigenous irrigation canalsthat lead water up mountainsides to terraced irrigated fields that are constructed by the villagers themselves astound modern engineers with their ingenuity. Twentyone provinces such as Jawzjan, Faryab, Balkh and Sari Pul, account for two-thirds of the vulnerable flood areas. In addition to the loss of homes, human and animal lives, and hundreds of thousands of hectares of agricultural land, contaminated water supplies cause multiple health problems worsened by destroyed roads that delay deliveries of emergency supplies. Displaced families suffer untold hardships.

Yet, settlements continue to be built in exposed locations because irrigated land is so hard to come by. Less than a quarter of the arable land is irrigated. Many families, especially across the north, depend on lalmi or dry-framing on steep waterless slopes of compacted soil unable to absorb sudden abundances of moisture. This sets off landslides. In May 2014 heavy rains in Badakhshan precipitated a massive landslide that buried a village under forty meters of mud and rocks. At least 300 lives were lost.

Outside the mountains other water systems are utilized. A system of underground canals called karezleads water from the foothills to village fields and can stretch for kilometers. To construct and keep them operating requires intensive specialized labor. Other types of water sources consist of: springs, canals, shallow wells that are vulnerable to fluctuations of the water table, tube wells, and large dams. It was Tamerlane's fourteenth century destruction of extensive irrigation networks in Hilmand province that turned what medieval geographers once called "the garden of Asia" into what is now known as Sar-o-Tar, Desolation and Emptiness.

Since 1972 rainfall has noticeably decreased while temperatures have risen. This brings draught to certain areas of the south as well as to the same flood-affected provinces. Draught, in combination with the increasing use of tube wells that lower water tables, affects vulnerable rural populations disastrously because in some areas eighty percent of the crops are damaged and countless cattle and flocks of sheep and goats are decimated for lack of fodder. Families are further impoverished when they lose jobs, spend all their assets and incur debt at a time of increased food prices. Consequently they suffer from malnutrition and associated illnesses. The only solution for many is to join the insecure ranks of internally displaced persons which rose from 80,000 in 2011 to 113,000 in 2013.

Isolation is another adverse factor. Extraordinary engineering feats were undertaken in the early twentieth century to facilitate trade and, more recently, for security reasons, but the road system remains woefully inadequate.Paved roads are largely confined to a ring around the central mountains which is still broken in the northwest. The dismal unpaved feeder roads confine the delivery of basic services and goods to remote villages to the backs of horses, donkeys, camels or human shoulders. At times the paths defy even these intrepid souls. Not surprisingly, rural-urban migrations increase as the transportation infrastructure improves,

According to informationin 2014from the Afghan Geodesy and Cartography Office, 31,230 villages dot the Afghan landscape, although other sources have listed as many as 40-90,000. They shelter populations with a mélange of backgrounds representing different ethnic groups that arrived over the centuries from different locations at different times. Generalities are almost always misleading. Once you make a flat statement someone, somewhere will prove you wrong, Nevertheless, a number of patterns may be noted. 
Anywhere from fifteen to over twenty ethnic groups are listed, the numbers hotly contested according to the political objectives of the reporters ${ }^{8}$. Broadly stated, the Indo-European speaking Pushtun ${ }^{9}$ and Baluch predominate in the south along with the Dravidian speaking Brahui; the Indo-European speaking Hazara ${ }^{10}$ largely occupy the central mountains; the Tajik, speaking various dialects of Indo-European languages, are spread across the north along with the Uralic-Altaic speaking Uzbeks ${ }^{11}$ and Turkmen. The Indo-European speaking Farziwan and Aymak inhabit the northwest. Two groups with unique cultural characteristics exist: the Nuristani $^{12}$ inhabiting eastern Nuristan province speak an Indo-European dialect, while the Uralic-Altaic speaking Kirghiz live in the high mountains of the Wakhan in the extreme northeast where the Afghan border touches China ${ }^{13}$ Minority groups of Hindus and Sikhs live in major cities where they are active in trade, commercial enterprises, money lending and homeopathic medicine, but their numbers have dwindled to around 1-2,000 in recent years.

Smaller villages normally consist of kin-related extended families. Larger settlements contain several ethnic groups living within self-contained kin-related sections. Grey zones of mixed ethnic settlements are particularly numerous in the north where history provides a complex picture of changing patterns. By the early nineteenth century powerful Uzbeks Khanates ruled all across the north from Maimana to Talaqan, but at the end of the century Amir Abdur Rahman broke their hold by shifting thousands of his Pushtun opponents, both sedentary and nomadic, from the south to the north ${ }^{14}$. New waves of Central Asian Tajik families also came down after the 1917 Bolshevik Revolution when Soviet land collectivization and hostile pressures on Muslim communities ignited the Basmachi revolts of 1921. Large-scale irrigation projects initiated by Kabul about the same time also changed the composition of northern villages

Nomadic pastoral and trading caravans have long been one of the more striking groups on the landscape. In the $1980 \mathrm{~s}$ the approximately 2.5 million nomadic groups were estimated to be eighty percent Pushtun and twenty percent Baluch. Today there are no accurate figures, but by all accounts their numbers have fallen to 1.5 million. The semi-annual nomadic migrations from winter quarters in low valleys to high summer encampments and back again are vitally important in maintaining marginal grasslands (L. Dupree 1980). Shepherds with large flocks of sheep and goats move up mountain trails while the silver-bejeweled women wearing bright heavily embroidered clothing ride camels with their children along the less precipitous lower routes. A few men on spirited horses escort them and fierce mastiff-like dogs guard families, shepherds and flocks. The sound of camel bells echoing off the mountains as they pass by at dawn is memorable. By mid-day they pitch their goat's hair tents on grasslands close to villages where they carry on a number of symbiotic activities.

Nomads exchange dairy products, animals for meat, tea, sugar, kerosene, guns, and ammunition for village grains, vegetables, fruits and nuts. The wealthier engage in money-lending and often acquire land when debts remain unpaid. Relations are not always cordial in every area for intense

\footnotetext{
${ }^{8}$ WAK Foundation 1999

${ }^{9}$ Spain 1972

${ }^{10}$ Mousavi 1998

${ }^{11}$ Lee 1996

${ }^{12}$ Dupree 1971b, Jettmar 1986

${ }^{13}$ Shahrani 2002

${ }^{14}$ L Dupree, 1980, P. 419
} 
competition over grazing rights often erupts. In the Hazarajat disputes have festered for generations. Factors associated with modern agricultural schemes and the changing nature of trade have altered old life-style patterns. Trucking companies have taken over many of the caravan activities and political events have disturbed migration routes. Therefore, many impoverished nomadic men have been forced to take up unskilled daily labor. At the same time, they watch services expand and keenly desire a share in education and medical assistance.

Over the years governments have tried to settle the nomads but none have been able to solve such matters as land allotments or access to basic services. Nor have the nomads benefited from lucrative aid programs because most donors find the logistical complexities too bewildering and prefer to work with them in the villages where they themselves have already partly settled. Nomads are also vulnerable to natural disasters and political events beyond their control. Since the locale of their residence is often difficult to define, they are underrepresented on local governance bodies and must fight to retain the ten seats reserved for them in the Lower House of Parliament. Predictions that nomadic life is coming to an end in Afghanistan have been around for many years (Ferdinand 2006), but despite enormous changes that have altered their way of life, they are learning to adapt and diversify. Some have now acquired land and are very wealthy. Still, they continue to extol the freedom they enjoyed in the past. The caravans will no doubt continue to enliven the landscape for at least another generation.

\section{LIVELIHOODS}

Aid providers tend to pay too little attention to the manner in which these disparate groups make their living because it is extremely complex. Also, because studies largely use standardized global definitions to determine where poverty lines lie without taking local variants into consideration conclusions can be misleading. According to World Bank figures for 2011, thirtysix percent of the Afghan population lives below the poverty line, mostly in villages, particularly in the northeast, central highlands and parts of the southeast. All indicators suggest increasing numbers of families will continue to fall into poverty because arable land is scarce, the transportation infrastructure is patchy, service deliveries are less than efficient, natural disasters occur annually and the insurgency perpetuates insecurity. Additional multi-dimensional factors such as inheritance traditions, social constraints, a disabling economic environment, weak governance and the dysfunctional rule of law may be added. Taken all together it would seem that today's poor will stay poor far into the future unless substantive changes occur.

Against these dire predictions one should mention the imaginative coping mechanisms together with an ability to diversify that allow countless rural families to avoid abject poverty.Most combine cultivating wheat and barley, the mainstay of the economy, with animal husbandry practiced by both sedentary and nomadic groups. However, competition over irrigated land and ethnic rivalries over pastures become serious economic issuesbetween sedentary and nomadic populations because the management of public lands is poorly defined. In addition, the appropriation of communal lands by wealthy landlords and political elites has worsened during the recent years of conflict giving rise to powerful warlords.

To minimize unexpected risks, an estimated fifty percent of rural families depend on a range of part-time work, including working the lands of others for a small portion of the crop. Others work as carpenters, masons, bricklayers, karez specialists, butchers, shoemakers, tailors, 
shopkeepers, or collectors of wood and wild plants.Mullahs are chosen by their communities and are paid in kind.Some groups also diversify household income through handcrafts such as carpet weaving and flat-weave gilims. The Turkmen are famous for their jewelry. Many seek work outside their villages, working as porters in near-by bazaar towns or eking out an existence as daily unskilled labor in large cities like Kabul. Minimal or no education and limited professional skills, however, keep wages to a minimum there. Going abroad as migrant laborers therefore becomes a popular option. Their remittances are essential sources of income for the survival of many rural families.

Women's contributions to household livelihoods are often trivialized and seldom represented in national production statistics. However, their management of household supplies is crucial to family well-being and their craft skills are often considerable, although recently an increasing number of aggressive merchant contractors have taken control of markets in an exploitive manner. This development is both economically and culturally worrisome for some leading carpet-weaving households which have upheld the high reputation of Afghan carpets in foreign markets for centuries have simply stopped weaving because profits have become so low.

Conditions in female-headed households are particularly vulnerable. There are no accurate figures, but it is estimated that some two million widows live in Afghanistan today. Many are young thirty-five-year-olds with an average of from one to five children. Widows with strong personalities who prefer to stay independent rather than accept advantageous proposals frequently become valued, respected members of communities where they make their living by performing a wide variety of useful services, especially as problem-solving liaison moderators between different ethnic groups. The lives of most women widowed by war or living with men disabled by war, however, must survive as dependents of others, sometimes with dignity but often in a constant state of crisis.

According to the Constitution and Islamic Law women are entitled to inherit land albeit at a ratio of two to one, in favor of males. The majority of rural women, however, surrender inherited land to fathers, brothers or sons because it is the custom, they are pressured to accept behavioral norms or simply because there are no able-bodied men in the household to work the land. Custom offers them few economic options. Social networks then become crucial in obtaining domestic work in the homes of landlords although wages for female domestics are significantly lower than even those for young boys who earn half the amount of adult males as shepherds or farm workers. Domestic working conditions vary by region. Groups living in mountainous areas practice more generous traditional patronage arrangements than therigidly hierarchical groups in the south who display more mercurial whims that keep women - and men - under constant fear of dismissal.

One last development of fairly recent vintage is the escalating poppy cultivation. Theuse of opium and other drugs to lessen aches and pains and quiet restless infants is not a recent phenomenon. But now Afghanistan has become the world's largest provider of opium. Cultivation rose thirty percent in 2013, and production surged to nearly six thousand tons which is eighty percent of global opium production. New technologies such as deep wells and herbicides and high demand, in South Asia as well as the west assure increases will continue.

The export value of opium in 2013 was worth some four million US dollars. However, the 200,000 individual farmers who cultivate poppies are paid hardly one-quarter of these huge 
earnings. The rest goes to government officials, landlords, warlords and drug traffickers. The drug trade not only fuels rampant corruption and drug-related crime, but threatens the nation's security. Nevertheless, income from poppy cultivation sustains farmers in provinces with the highest volume of production such as Hilmand and Kandahar, Kunar and Badakhshan. Sporadic attempts to introduce crop substitutes over many years since the 1970s have been less than successful in most areas. Campaigns to eradicate poppy crops, on the other hand, simply drive cultivation into areas once deemed poppy free, such as Ghor, Laghman and Balkh, leaving famers in the old areas economically destitute.

Over eight billion US dollars have been expended on counter-narcotic programs but all are fragile and collapse easily. The challenges involve complex political issues way beyond cultivation and economics. The simplistic one-dimensional measures found in much of counternarcotic policy planning and implementation too often fails to reflect this. The drug business is so lucrative that keeping it at the centre of patronage becomes an overpowering imperative as governments are disinclined;to introduce counter-narcotics measures for fear of alienating rural populations or the traffickers so closely tied to the pinnacles of power.

\section{SOCIAL PATTERNS}

Afghan society may be described as patriarchal with authority vested in the hands of men, patrilineal with inheritance passing through the male line and patrilocal with girls moving on marriage to the home of the husband. Because governmentinstitutions in rural areas are weak or even non-existent, individuals must look to family for their socio-economic and political rights, from birth through old age. In return they acknowledge and readily accept clearly defined reciprocal obligations. The family thus functions as the single most important institution in this society. It was this family solidarity that enabled Afghans to endure years of traumatic displacement in exile from which they emerged with their essential values battered but intact. And, it is these strong social support mechanisms that sustain their resilience in coping with the hardships of rural life today.

Islam abides at the chore of village life and provides a system of behavior codes by which they live $^{15}$. Mosques occupy a central place in village life. In addition to being used for religious rituals, mosques serve as the focal point for all important decision-making, problem solving and news sharing. At times they shelter travelers.Mullahs, the caretakers of mosques, chosen and paid by their communities,conduct all religious activities such as running a school for religious instruction, naming children, performing baptisms, circumcisions, weddings and burials. They prepare amulets, tawiz, to ward off evil eyes and assure peace in households with multiple wives $^{16}$. Visits to religious shrines are much enjoyed outings, especially for women who have few other opportunities to leave the village. Men from villages clustered around towns, on the other hand, visit weekly bazaar days in town where they strengthen social and political ties, cultivate relationships and share news.

Listening to folk tales is another popular form of entertainment that has numerous cultural and social functions. The tradition of associating hallowed locations with esteemed religious personages is widely manifest in Afghanistan although Islam does not encourage saint cults. Sites all over the country are intimately related to Islam, linked with Islamic events or

\footnotetext{
${ }^{15}$ Olivier Roy 1986

${ }^{16}$ N. Dupree, 1974
} 
personalities and miraculous acts often believed to have taken place in the immediate surroundings of certain villages. Visits to these shrines offer hope for sought after boons, cures or solace and serve to bond individuals to their heritage. The tales also emphasize Islamic ideals, caution and instruct, and define exemplary behavior. They justify group existence by recounting heroic family exploits, thereby reinforcing group pride. Folk tellers and poets are greatly admired, especially on festive religious holidays in the cities which draw large crowds of men and women from near-by villages ${ }^{17}$.

New patterns of illicit drug use for entertainment have been on the rise since repatriation began. Over one million Afghans are said to be affected. Most live in cities, but growing numbers are found in rural areas where users are blissfully unaware of the costs to health and society. No longer used just to relieve aches and pains and quiet restive infants as it was in the past, opium is now seen as a pleasant social recreation. Addicted males persuade women in their families to join them, often for companionship but also in the belief that once they become dependent on drugs they will be less inclined to run away. Once addicted, women then persuade other women to join them and since most families are kin-elated the entire village soon becomes engaged in what appears to them to be an acceptable social pastime. Sadly, children born to these women enter this world already addicted. This is a severe problemthat is bound to worsen as it has yet to attract the attention of serious researchers

Contrary to stereotypical images portraying them as little more than ignorant chattel with no egos and valued only for their reproductive services, women play multiple roles so interconnected with those of men in the economy of the household that they form bonds of mutual respect. Individual women achieve status and gain respect as they progress from child, to wife, to mother to grandmother and also in the way they manage household supplies, conduct domestic chores, process food and raw materials. Elderly women are expected to pass on the society's values to the young. Women's networks maintain family solidarity, arrange marriages, organize religious gatherings and outings, mediate family and neighborly disputes, provide communication links and supply moral and economic support during crises. It is this multiplicity of meaningful activities that gives them a sense of identity which manifestly contributes to the quality of women's lives no matter how limited their surroundings may be.

Against these positives there is a dark side. In this conservative patriarchal society male honor reigns supreme. It is the rock upon which social status rests, and women are seen as the measure by which standards of morality are judged, as the guardians of society's values. Any deviation from accepted norms of female behavior cannot be tolerated.Women are killed in the name of honor for simply running away to avoid unpalatable marriage alliances, for allegedly engaging in illicit affairs, or for eloping. Others are beheaded for daring to divorce. Many endure torture and physical disfigurement for refusing to obey, for not having children, or for not producing sons. Summary community ad hoc extrajudicial trials end in execution, often by stoning. Such deeply felt emotions gave rise to the practices of keeping women veiled in public and the institution of purdah, seclusion.

Both men and women are wary of approaching offices in the formal legal system because it is cumbersome and slow, costly in fees and bribes, intimidating, humiliating and even abusive. Generally speaking women prefer to resolve their justice needs within their families or

\footnotetext{
${ }^{17}$ N. Dupree, 2003, P. 526-28
} 
communities even though too often it is close family members who inflict the harshest cruelties. And, it is conservative community councils who summarily condemn to death those suspected of besmirching community honor without examining the evidence. Even so, women are still hesitant to enter the hostile environments of the formal legal system for, in addition to not being sympathetically listened to, they must consider the social consequences of bringing private issues before outsiders which is viewed as shameful and dishonorable behavior for which they must risk social stigma, increased physical abuse, the loss of parental custody as well as social and economic support. ${ }^{18}$

Only a limited number of female lawyers and judges work in the formal provincial legal system and male judges, largely impatient with women's problems, tend to send them home where they think they belong even though they know it means sending them back to continued domestic violence. For women who do not read and write, courts are intimidating, the legal language is almost impossible to understand so it necessary to be escorted by male family members who are often the root of their problems. In addition, rural women often do not possess the many documents needed to move cases forward, nor are they able to meet the costs of fees and transportation. Increasing numbers of concerned state offices, civil society groups, and nongovernmental organizations (NGOs) have now set up provincial offices which is heartening, but it is difficult for women to access them. These are just some of the many reasons that persuade women to remain at home no matter how harrowing it may be.

The importance of privacy for women is underscored by architecture. Qalas, a prominent housetype in Pushtun areas, may accommodate several nuclear households averaging eight persons, in addition to extend families of grandparents, unmarried aunts, uncles and widows. Each unit has its own private space, but shared work and entertainment take place in a courtyard set behind a wall dividing the women's quarters from space inside the qala's singleentrance where men are entertained. Elsewhere otherhouse types consist of flat-roofed, square or rectangular structures constructedalso of sun-dried bricks covered with mud and straw plaster. Some groups are fond of verandahs overlooking gardens and work spaces. In the west and in some areas of the south, domed roofs covering a series of square, interconnecting rooms predominate ${ }^{19}$. No matter the style, all residential homes are protected by high walls lining winding streets that are mostly empty during the day allowing women freedom to circulate freely.

Because in the past outsiders have come mostly to extract taxes, conscripts for the army, or women for harems, rural communities tend to be wary of outsiders and meet them with a first line of defense while the real leaders sit in the shadows. Such inward-looking protective strategies have been misinterpreted as indicating rural antipathy to new ideas. This is patently untrue. Villagers quickly adopt new ways as long as the benefits are clear and the manner in which they are introduced is deemed worthy of trust. Without these essential ingredients there is little chance of success.

This was all too evident in the 1970s when zealous urban reformers arrived in villages spouting leftist revolutionary rhetoric discrediting cherished traditions and proclaiming drastic changes to come. They were summarily rejected. Programs conceived by outsiders, no matter how splendid they may seem on paper, will come to naught if they do not address the felt-needs of rural

\footnotetext{
${ }^{18}$ Luccaro and Gaston, 2014

${ }^{19}$ Szabo and Barfield, 1991
} 
populations. As simplistic as this may seem, experience has proven its basic validity. Changing attitudes requires understanding on both sides and considerable patience. It is not just a question of distributing large sums of money, and certainly quick fixes demanding instant implementation are not sustainable. The various actors who have met with success over years of effort have learned this lesson well. It is those who look only at the emergency of the "big picture" who must be persuaded to find more appropriate approaches.

\section{REACHING OUT}

Formal efforts to improve rural environments have been launched for over a century ${ }^{20}$, often times chiefly to present an image of a nation worthy of respect by other nations. Results have been mixed,but recently encouraging signs of greater effectiveness are evident within government institutions, and among a growing number of NGOs and civil society groups. International NGOs from countries across the world arrived on the scene for the first time to assist Afghan refugees in neighboring countries. Later they were joined by many Afghan NGOs. Most are heavily dependent on foreign donor funding. Some, particularly those working in health, education and veterinary services, have achieved impressive results. To ease the perpetual worries over scarce funding and shortage of qualified staff, many rely on approaches that require considerable community responsibilities.

The civil society networks that blossomed after the refugees began to repatriate engage in many different causes but are known largely for their work on human rights and social issues. More recently they are effectively confronting politicians demanding people-oriented platforms. They are opening many more offices in the provinces and gaining a reputation for effectively addressing grievous challenges previously considered too sensitive to confront. The alacrity with which these organizations mobilize public demonstrations when special cases arise is new and impressive. Critics carp about the relatively small numbers now involved without realizing that it is the initial few that lead the momentum that implants awareness. Civil societies will undoubtedly increase their power in the rural area in the coming years.

Education.Education has long been a treasured ideal since seeking knowledge is sanctified by the Islamic instruction that all good Muslims should be educated so as to provide social justice for their communities. Constitutions have obligated the state to provide every child free compulsory primary education, but in fact education is out of reach for most. Nevertheless, over the years a network of secular village schools was established, although plagued by mammoth problems that persist. The curriculum is largely unrelated to the needs of rural children, too many teachers are barely literate, attendance is irregular, the dropout rate is high and the pervasive reliance on rote learning discourages critical thinking, inquiring classroom interchanges or the attainment of problem-solving skills. Furthermore, after the 1978 leftist coup, aversion to these secular schools arose particularly within rural populations as they were seen as the road along which communism, the massive flow of refugees and untold hardships travelled

Over long years of exile the anathema towards secular education lessened as the benefits were slowly realized. Despite vestiges of conservative opposition, the demand for schools is now high

${ }^{20}$ N. Dupree, 2000, 12-26 
and the government is responding. The Ministry of Education 2013 list of over 15,000 schools includes some 3,000 located in rural areas,attended by over three million students, including a million girls. Still, the literacy rate hovers around thirty-four percent and the effectiveness of rural schools is curtailed by serious inadequacies. Funding is scarce, there is a severe shortage of buildings, supplies and textbooks, and a minimal number of trained teachers. The dropout rate is high because village boys are needed for gainful employment and girls are usually pulled out of school at puberty. As a result, a high portion of rural youth is unable to read or write.

But the use of literacy rates as an indicator of meaningful educational attainment is shortsighted. Much time and millions of dollars have been spent on literacy courses recently, but these wellintentioned efforts are largely wasted because too many implementers refuse to realize that literacy alone is merely a tool that opens horizons of knowledge to enhance the quality of life. To be effective literacy must be coupled with the provision of an infinite variety of reading matter. This in turn requires the massive production and distribution of easy-to-read material to sustain the newly acquired reading and writing skills of the new literates. Until planners begin to capitalize on the now evident thirst for education by moving such comprehensive approaches to a position of top priority, the development of a society well-informed on social, economic and political essentials will be delayed indefinitely.

Health. For most living in the rural areas, men, women and children, access to medical services is their most pressing immediate need. The tragedy is that many perish needlessly because eighty-seven percent of the diseases that bring death are preventable. Happily, although the ongoing conflict causes widespread disruption of services, the health sector may be seen as a beacon of success.

Health problems stemming fromcultural and social behavior inimical to healthy lifestyles are exacerbated by high illiteracy that perpetuates ignorance of basic good health practices. In addition, qualified health professionals were for long loath to serve in the countryside. However, this has improved over the past sixty years since a series of successful eradication campaignswere launched targeting specific diseases. Malaria decreased significantly. Only sporadic outbreaks of small pox imported from Pakistan occur because of increasingly effective immunization efforts. Massive recurring campaigns attack polio, now down to two cases also imported across the border from Pakistan. Assaults on TB, however, have been less successful.

Changing attitudes and behavior patterns are vital for success. Considerable attention has been given, therefore, to the deployment of male and female Community Health Workersat grassroots levels. This innovative, broad-based, nation-wide network is composed of volunteers selected by their communities from various segments of village life. They may be farmers, shopkeepers, teachers, housewives or religious leaders. Now numbering over 20,000 they are trained for six months to treat simple ailments, but most importantly to mobilize their communities to utilize available health-related services. They serve as a vital link between villages and the greatly improved National Health Service.

Such initiatives have contributed to a sustained reduction in mortality rates. It is difficult to select numbers for typically they depend on the source one trusts, but all are dramatic. An average rural woman gives birth to seven or eight children. Figures in 2001 for maternal mortality in Badakhshan showed an astounding rate of 1600 per 100,000 live births which the Ministry of 
Public Health says has now slid to 327/100,000. Infant and under-five rates that previously ranged in the high hundreds have decreased to the low hundreds. Sustained efforts directed toward these issues by government and the aid community have focused largely on midwifery training of all sorts at all levels, persuasion, immunization, community awareness, coordination and forging links within the health infrastructure.

Also of special concern for Afghanistan are some 800,000 persons with disabilities, mostly residing in villages. The war-injured enjoy the status of heroes, but those with birth-related disabilities suffer most from negative attitudes that lower their self-esteem. Rejection or acceptance depends in large part on the extent to which individuals are able to fill expected roles in society: males providing links outside the family and income to sustain it; women bearing children and nurturing the family. The distress felt by Afghan women unable to marry and produce children cannot be overemphasized. Programs to address both physical and social disability issues began among the refugees in Pakistan in 1991 and greatly expanded after repatriation. The Afghan NGOs working in this sector are particularly active and successful.

The cherished ideal for achieving a dignified integration of disabled persons into society focus on advocacy, equal opportunities in education, jobs and technical training as well as an equitable distribution of services and resources. The major strategy is embedded in a system known as Community Based Rehabilitation that relies heavily on workers drawn from communities to raise local awareness, engage in home-based training and initiate referrals. This relies on sustained commitment by a large group of people, from families and local officials to professional technicians of all sorts, not to mention the massive amount of training required or the referral networks needed for support. The sheer numbers of individuals that must be involved to achieve success is staggering.

Agriculture: Afghanistan's economy rests on agricultural and animal produce, although crops cover less than ten percent of the land area which is a fraction of its potential capacity. Much of the rest of the land is covered by grazing pastures for large herds of sheep and goats tended by sedentary as well as nomadic groups. Wheat, barley, corn and rice are the traditional mainstays with cotton and pulses also important. But the country has long been known primarily for its fine fruits, and nuts. Ninth century sources report that melons from Balkh were packed with ice in leaden molds and sent to grace the table of the Caliph in Baghdad. They are as prized today, along with grapes, raisins, pomegranates, apricots, cherries, figs and more, in addition to almonds, walnuts, pine nuts and pistachios. Lack of refrigeration for fresh fruits and unsanitary packaging for dried fruits, however, keep profits low.

Attempts by governments to repair the devastation wrought by Tamerlane and make the desert bloom in the Hilmand began as early as 1910 and intensified after the Second World War. Huge dams to feed a massive irrigation infrastructure were built. It failed initially because the poor design created extensive salinization so it continues to remain a major focus for the agricultural sector today. Large hydro-electric dams constructed in the vicinity of Kabul by the West Germans (1953) and the Russians (1966) continue to function well. However, despite billions of dollars recently invested on ambitious irrigation projects the results, with some notable exceptions, continue to be mixed because of continued poor planning. 
Initiatives at village levels covering a wide variety of projects have been successful in the improvement and multiplication of seeds, disease control for both plants and animals, and veterinary services. Training of all sorts is ongoing. What are missing are regional approaches that integrate projects from the first planted seed through the construction of easily maintained, community constructed dams for electricity as well as water to small processing factories and marketing networks. Integration with public and private sectors, farmers and businessmen, would also stimulate the economy, revive agro-businesses and invigorate the agricultural sector by keeping rural populations employed in their home areas. Such comprehensive approaches, however, have yet to attract strategy planners.

Governance: Provincial governors are appointed by the president. In these highly lucrative patronage positions governors exercise great power either as forces of beneficial change or corrupt exploiters in league with large landlords and political elites. They carry out what the 2004 Constitution explicitly upholds as "preserving the principle of centralism," although it also calls for the election of Provincial Councils in each province to set rural development priorities. The size of the membership of these thirty-four Provincial Councils established in 2005 is based on the population of the province. Their rolesremain disturbingly vague, however, for they are imprecisely defined in the Constitution as "taking part in securing development targets" and "giving advice to the administration." They are universally underfunded, poorly equipped, weak and mostly ineffectual for the central government consistently resists surrendering real decisionmaking powers to them, and, the international community gives them scant attention. But they are in place and await transformation into forceful local bodies.

Reserved seats on Provincial Councils encourage women to participate, but many remain empty because of social constraints that limit their participation, particularly in the conservative southern provinces. Female councilors are often harassed and even assassinated. Those who do have the courage to serve are then mostly given minor secretarial tasks and complain that male members, who outnumber them three to one, withhold funding for women-oriented projects. But holding back operating funds concerns men as well and keeps all Provincial Councils from performing effectively. Because of this NGOs often co-opt assistance funding that should be utilized for healthy community participation.

In 2003 a vast network of Community Development Councils (CDCs) administered by the Ministry of Rural Rehabilitations and Development was introduced under a program called the National Solidarity Programme to help communities identify, plan and manage priorities through strengthening local governance, establishing community-managed projects, and improving access of rural communities to social infrastructures and services. There are now 33,000 CDCs functioning, with plans to increase them to 44,000. This program is generously funded by international donors and works with many NGO partners. Some function well, but in some areas they are dominated by wealthy landlords and political elites who siphon off much of the assistance packages.

\section{TODAY}

Such initiatives account for only a small part of the cascade of foreign monies that has flowed into Afghanistan over three decades. Yet public perception holds that claims of significant improvements are exaggerated because of patchwork planning, too much money indiscriminately distributed and too great reliance on quick fixes requiring instant 
implementation rather than sustained engagement. Afghanistan has become almost totally dependent on outsiders. Not surprisingly, the regard for both government and assistance providers has fallen gradually to its lowest ebb. The problems lie primarily in the failure of planners to abide by long-established fundamental development principles. The need now is to shift from just infrastructureand service deliveries, as essential as these may be, to a bottom-up strategy beginning with rural communities buttressed by a strong local governance infrastructure.

Moving from an aid-dependent to an independent self-reliant state requires bolstering the stature of Provincial Councils, among many other things. The Presidential and Provincial Council elections of April 2014 were initial steps in this direction. Preparations began in July 2013 when Parliament approved a Law on the Structure and Duties of the Independent Electoral Commission (IEC) and its companion body the Independent Complaints Commission (ECC) to maintain credibility and transparency. To avoid the taint of patronage the Law removed the power to appointment members of the IEC from the President by establishing a prestigious committee to recommend a shortlist for appointment representing a balanced mixture of experience, ethnic group and political affiliation. A legal framework to work with was thus provided.

At the same time, the insurgents vowed to disrupt the process by attacking polling stations and harassing citizens on their way to vote. To allay these fears, the Army and Police mobilized a force of 380,000, backed by 53,000 international coalition troops. Most significantly, concerted efforts were undertaken to overcome the traditional apathy with which elections were generally regarded in the past, stemming from the widely-held conception that elections were merely regional popularity contests centered on single personalities and ethnicity. A robust media blitz was launched using radio, TV, social media, and cell phones in addition to the enlistment of over three thousand donkeys to carry messages and materials to remote rural areas. This stimulated an election fever that gradually suffused the entire country.

The initial round in April was a ground-breaking success despite technical difficulties. The turnout of over seven million or sixty percent of the eligible voters exceeded expectations. The security forces manfully held insurgency attacks to a minimum. Almost three thousand candidates,many now educated, forward-looking youth, ran for Provincial Councils: 458 won, including ninety-six women. Some will undoubtedly be co-opted by old -guard political networks to maintain control, but others are genuinely committed to their constituencies. Inexperience and limited access to funding other than those manipulated by old-time power brokers may limit their effectiveness initially, but their expertise in employing the latest in communication technology extends their outreach significantly ${ }^{21}$. A promising future is anticipated.

An exultant mood was palpable. Confidence in the abilities of individuals and purely Afghan institutions was high. This lasted for far too short a time, however, as evidence of massive fraud surfaced. The ebullient mood evaporated quickly and was replaced by disillusionment as the two contending candidates remained deadlocked over the validity of the vote count. Shocking reports of alleged involvement of IEC and ECC members as well as provincial

\footnotetext{
${ }^{21}$ Hawad, 2014
} 
government officials circulated. Time was running out for a new leadership was urgently needed to ensure stability after the scheduled December withdrawal of foreign troops. At the same time intensified insurgency attacks rocked villages and cities throughout the country.

After weeks of bitter dispute a run-off was hastily organized in June that brought even greater accusations of fraud, dangerously centered this time on ethnic divides. The announcement that the turnout was 8.1 million raised eyebrows for observers consistently reported much lower attendances at polling stations than was seen during the first round in April. Protestors took to the streets of Kabul and dire warnings that violence would engulf the nation were rife. It took nearly a month and frantic efforts by international brokers to break the deadlock with an agreement calling for an audit of the entire 8.1 million votes. The agreement also proposed to establish a National Unity Government with the winner as president of the state and the loser heading the government as prime minister. Changing to a parliamentary-like system will necessitate amending the Constitution, but details have yet to be determined. Meanwhile the nation waits with uncertainty

The recount is an enormous task that is expected to take a month after the ballot boxes are transferred by international military helicopters from 23,000 polling stations in the provinces to the IEC offices in Kabul. Foreign forces will guard them throughout the audit. Trust in Afghan capabilities has largely vanished. The thorny issue of determining how fraudulent ballots will be identified slowed down the process after only four days. The whole process will be supervised by United Nations monitors and watched by agents from each campaign as well as hundreds of national and internationals observers. The contending candidates have publicly endorsed the terms of the agreement and said they will consider the results binding. That remains to be seen. Another extremely worrying unknown is whether the followers of the looser will necessarily accept the results and whether he will be able to control them if they do not. .

So Afghanistan must yet again contend with a debilitating political crisis of immense proportions. While it waits, the momentum stimulated by positive attitudinal changes will continue to reach out to rural areas, albeit delayed by the political crisis. The demand for secular education is high. Basic health messages are being heard. An increasingly vibrant civil society nurtures greater awareness of human rights in the provinces. The youth and women participate actively beyond urban settings. The need for law reform is widely acknowledged. Expanding communication systems narrow the rural-urban gap. The promotion of national unity can be a major force if only it materializes. Many challenges remain, many spoilers lurk behind the scenes. Nevertheless, Afghanistan is on the threshold of transformation. Hopefully this will be reflected in the lives of rural families.

\section{REFERENCES}

Aschenbrenner, Maria and Kristiansson, Bengt (eds.), 2005. Afghanistan: A Developing Democracy? Stockholm: Swedish Committee for Afghanistan

Ball, Warwick, 1982. Archaeological Gazetteer of Afghanistan, 2 vols. Paris: Editions Recherche sur les civilisations 
Crowley, Joe, 2014. Archaeology and Population Maps included with this chapter.

Dani, Ahmad Hasan, 1981. Indus Civilization: New Perspectives, Islamabad, Pakistan: Quaid-iAzam University

Dupree, Louis, Phillipe Gouin, Najibullah Omer, 1971a. 'The Khosh Tapa Hoard from North Afghanistan', Archaeology 24.

Dupree, Louis, 1971b. Nuristan: "The Land of Light” Seen Darkly, American Universities Field Service South Asia Series 15/6. Hanover, New Hampshire: American Universities Field Staff

Dupree, Louis, Angel, Lawrence, Brill, Robert, Caley, Earle, Davis, Richard, Kolb, Charles, Marshack, Alexander, Perkins, Dexter, Solem, Alan, 1972. Prehistoric Research in Afghanistan (1959-1966), New series 62/4 Philadelphia: American Philosophical Society

Dupree, Louis and Davis, Richard, 1976. 'New Prehistoric Localities in the Dasht-i-Nawar', Afghanistan 20/3

Dupree, Louis, 1980. Afghanistan. Princeton: Princeton University Press; 1987 Karachi: Oxford Pakistan Paperbacks, 2nd edition.

Dupree, Louis, 1981. 'Notes on Shortugai: an Harappan site in northern Afghanistan', in Dani (ed.) Dani, Ahmad Hasan, 1981. Indus Civilization: New Perspectives. Islamabad, Pakistan: Quaid-i-Azam University

Dupree, Nancy 1974. 'An Interpretation of the Role of the Hoopoe in Afghan Folklore and Magic', Folklore 85:173-193

Dupree, Nancy, 2003. 'Sacred Geography', in Mills, Margaret, Claus, Peter, Diamond, Sarah (eds.) 2003. South Asian Folklore: an Encyclopedia, Afghanistan, Bangladesh, India, Nepal, Pakistan, Sri Lanka, New York: Rutledge Press

Dupree, Nancy, 2006. 'The Backdrop to Change: A Scenario for Development', in Aschenbrenner and Kristiansson (eds.), pp. 13-131.

Ferdinand, Klaus, 2006. Afghan Nomads: Caravans, Conflicts, and Trade in Afghanistan and British India, Copenhagen: Rhodos International Science and Art Publishers

Hawad, Gran and Johnson, Casey, 2014. A Rough Guide to Afghan Youth Politics, Washington DC: United States Institute of Peace.

Jettmar, Karl, 1986. The Religions of the Hindukush: the religion of the Kafirs the pre-Islamic Heritage of Nuristan, New Delhi: Oxford \& IBH Publishing

Luccarao, Tim, Gaston, Erica, 2014. Women's Access to Justice: Individual versus Community Barrers to Justice, Washington, DC: United States Institute of Peace 
Lee, Jonathan, 1996. The 'Ancient Supremacy': Bukhara, Afghanistan and the Battle for Balkh, 1731-1901. Netherlands: E, J. Brill

Maley, William (ed.), 1998. Fundamentalism Rebocrn?: Afghanistan and the Taliban, London: Hurst \& Co.

Mills, Margaret, Claus, Peter, Diamond, Sarah (eds.), 2003. South Asian Folklore: an Encyclopedia, Afghanistan, Bangladesh, India, Nepal, Pakistan, Sri Lanka, New York: Rutledge Press

Mousavi, Sayed Akbar 1979. The Hazaras of Afghanistan: an historical, cultural, economic and political study, Tehran: Al-hoda Publishers

Rowland, Benjamin and Frances Rice, 1971. Art in Afghanistan: Objects from the Kabul Museum, London: Allen Lane Penguin Press.

Roy, Olivier 1986, Islam and Resistance in Afghanistan, Cambridge, U.K.: University of Cambridge Press

Sarianidi, Victor, 1985. Bactrian Gold from the Excavations of the Tillya Tepe Necropolis in Northern Afghanistan, Leningrad: Aurora Art Publishers

Shahrani, Nazif, 2002. The Kirghiz and Wakhi of Afghanistan: Adaptations to Closed Frontiers and War, Seattle: University of Washington Press

Spain, James, 1972. The Way of the Pathans, Karachi, Pakistan: Oxford University Press

Szabo, Albert and Barfield, Thomas, 1991. Afghanistan: An Atlas of Indigenous Domestic Architecture, Austen: University of Texas Press

WAK Foundation, 1999. The Ethnic Composition of Afghanistan: a six year survey and research (1991-1996), Peshawar, Pakistan: WAK Foundation 